\title{
British New Left's Multiple Paradigm Analysis and Theoretical Review of Marxist Cultural Theory
}

\author{
Xianyue Li \\ School of Marxism, Shanghai University of Political Science and Law, Shanghai, China \\ Email: lixianyue@shupl.edu.cn
}

How to cite this paper: Li, X. Y. (2022). British New Left's Multiple Paradigm Analysis and Theoretical Review of Marxist Cultural Theory. Open Journal of Social Sciences, 10, 240-255.

https://doi.org/10.4236/jss.2022.101020

Received: December 10, 2021

Accepted: January 21, 2022

Published: January 24, 2022

Copyright $\odot 2022$ by author(s) and Scientific Research Publishing Inc. This work is licensed under the Creative Commons Attribution International License (CC BY 4.0).

http://creativecommons.org/licenses/by/4.0/

\begin{abstract}
Since the 20th century, culture has gradually become the central discourse, becoming increasingly complex and difficult to understand. The current academic research on Marxist cultural theory is more based on the perspectives of cultural and political philosophy, while the inspection from the perspective of paradigm has not been fully reflected. This paper attempts to sort out the multi-dimensional paradigm analysis of Marxist cultural theory by British New Left and clarify how they solve the cultural crisis by reconstructing cultural concepts. Firstly, by re-exploring the relationship between culture and the base/ superstructure theory model, breaking the shackles of economic determinism and releasing the relative autonomy of culture. Secondly, focus on the materialist view of culture, criticize elitism, and stimulate the political liberation potential of culture. Finally, combine ideology and hegemony theory to solve the cultural structure and subject dilemma. After the transformation of multiple paradigms and theoretical disputes, British New Left has expanded the interpretation space of Marxist cultural theory, but it has also gradually fallen into the whirlpool of postmodernism and has drifted away from historical materialism.
\end{abstract}

\section{Keywords}

British New Left, Culture, Paradigm, Marxist Cultural Theory

\section{Introduction}

Since the 20th century, the cultural crisis triggered by modernity has always been an important issue faced by Western society and has gradually become the focus of research (e.g., Williams, 1983; Anderson, 1979; Lu, 2018). The field of cultural contention has shifted from focusing on class inequality to gender inequality or 
racial inequality, from focusing on the economic exploitation of workers in the field of production to the spiritual oppression of disadvantaged groups in the cultural field, constantly bringing new challenges to Marxism (e.g. Hall, 1980; Williams, 1983; Kellner, 2021). The current academic research on Marxist cultural theory had achieved certain research results. In general, it analyzed Marx's cultural theory from the perspective of cultural philosophy and political philosophy (e.g. Li \& He, 1989; Huang, 2002; Liu, 2011), examined Marx’s original work from the perspective of the construction process of Marx's historical materialism (e.g. Hu \& Guo, 2010; Sun \& He, 2011), and interpreted Marx’s cultural thought from the real cultural realm (e.g. Lin, 1993; Kenny, 1995; Dworkin, 1997; Davis, 2006; Yu, 2001). It focused on presenting the appearance of its cultural outlook as a whole, but these tended to give rise to the tendency of emphasizing the past over the present, generalizing the study of the history of thought, and lacking paradigm analysis. Different from other scholars' textual analysis of Marx's original works, the British New Left's multi-paradigm analysis of Marxist cultural theory is more based on the investigation of British social issues and cultural theoretical crises. They rethink the relationship between culture, politics, and economy, try to break the shackles of economic determinism, release the relative autonomy of culture and the potential for political liberation, re-examine the status and role of mass culture and working-class culture, and open up a new path to socialism. However, influenced by different theoretical resources and political backgrounds, the paradigm of British New Left cultural research has shown a multi-dimensional nature, with constant paradigm shifts, solving the subjective agency problems of culture, developing Marxist cultural theory and expanding the field of Marxist cultural research. In hence, it is of great significance to review the British New Left's analysis of Marxist cultural theory based on a multi-dimensional paradigm perspective, to clarify the cultural theoretical disputes and development logic, and to provide a new perspective for deepening the study of Marxist cultural theory.

\section{Reinterpret the Relationship between Culture and the Base/Superstructure Theory Model and Release the Relative Autonomy of Culture}

Since Marx and Engels made a "metaphor" expression of the relationship between the base and the superstructure in Marx's 1859 Preface to A Contribution to the Critique of Political Economy, the theory of "metaphor" has been controversial (Althusser, 2005; Williams, 1977; Thompson, 1957). Especially under the influence of Soviet Marxism, the base/ superstructure theory model has gradually been ossified into economic determinism and simple reductionism. In Britain in the 1950s, this mechanical determinism continued to ossify Marxist cultural theory. Culture "normally indicates, in their writings, the intellectual and imaginative products of a society; this corresponds with the weak use of 'superstructure'." (Williams, 1983: p. 282). This narrow understanding is not conducive to breaking the opposition between elite culture and mass culture, nor is it 
conducive to realizing the unification of the base and the superstructure. The British New Left tried to start from experience, re-examine the relationship among culture, politics, and economy based on different analysis paradigms. They try to emphasize the subjective agency and material meaning of culture and release the relative autonomy of culture (Williams, 1958; Thompson, 1957; Hoggart, 1957). Focusing on the controversy caused by the base/superstructure theory model, Thompson tried to use the historicism analysis paradigm to criticize Stalinism, highlight the subjectivity of culture, and emphasize that the base/superstructure theory is a metaphorical theory. Following the analysis of Thompson's metaphorical theory, Williams tried to break through the constraints of economic determinism, starting from etymological analysis, deeply analyzing the connotation of keywords such as the base and the superstructure, and emphasizing the materiality of culture.

\subsection{Through Historicism Analysis, Criticize Stalinism and Highlight the Subjective Agency of Culture}

"Any modern approach to a Marxist theory of culture must begin by considering the proposition of a determining base and a determined superstructure" (Williams, 1977: p. 75). Continuing the Western Marxist emphasis on experience (e.g. Lukács, 1972), the first generation of the British New Left headed by Williams and Thompson also tried to find a breakthrough from experience and expand the connotation and extension of culture. They tried to use the concept of holism to break the dualistic model of the base and the superstructure, to get rid of the shackles of Stalinism, and to release the relative autonomy of culture.

Based on the "metaphor theory", through the historicism analysis of the experience of the struggle of the British working-class from the 18th to the 19th century, E. P. Thompson tries to go deep into the daily life of the masses, highlighting the initiative of the subject, and revising the base and superstructure theory model. In Thompson's view, the real social history is a complete organism. The base and the superstructure belong to the category of epistemology and influence each other. If we follow Stalinism and regard the base and superstructure as the category of realism, it is easy to distort the relationship into action and reaction in the sense of physics. If social history is ossified into a mechanical device, the individual as the subject of history will disappear and deviate from Marx's original intention (Thompson, 1957). Based on the perspective of social integrity, Thompson examines the social and historical organism from the realistic individual, takes experience as the mediator, connects social existence and social consciousness, and reinterprets culture as a whole. By examining the struggle experience of the British working class from bottom to top and stimulating the initiative of the subject, Thompson emphasized the structural role of culture in social development, which can constantly generate class and class consciousness, thus dispelling the rigid pattern of Stalinism. 


\subsection{Through Etymological Analysis, Transcend Economic Determinism and Highlight the Materiality of Culture}

Continuing Thompson's logic of "metaphor" theory, based on the investigation of Marx's 1859 Preface to a Contribution to the Critique of Political Economy and The Eighteenth Brumaire of Louis Napoleon, Williams borrowed the literary analysis from F. R. Leavis. He emphasized that the meaning of superstructure and base is uncertain, and the process of meaning change is not so much a precise meaning, but more like a metaphor. In the use of 1851-2, the foundation is absent. "The origins of a particular form of class consciousness are specified as 'forms of property' and 'social conditions of experience'. In the use of 1859, it appears in almost conscious metaphor: 'the economic structure of society-the real foundation (die reale Basis), on which rises (erhebt) a legal and political superstructure (Überbau)'. It is replaced, later in the argument, by 'the economic foundation"” (Ökonomische Grundlage) (Williams, 1977: p. 77).

Through the etymological analysis of keywords such as base and determination, Williams tried to break the shackles of economic determinism. He pointed out that "it is part of the complexity of the subsequent argument that the term rendered in English explication (probably first by Engels) as 'base' is rendered in other languages insignificant variations (in French usually as infrastructure), in Italian as struttura" (Williams, 1977: p. 77). The corresponding Chinese is the foundation, infrastructure, and structure, which cannot be simply covered by the economy. By examining the change of the meaning of "determine" and "determination", Williams stressed that "determination" should be understood as setting boundaries and exerting pressure, which is a positive and active behavior, rather than external abstract control. Then, from the perspective of cultural materialism, Williams revised the base/superstructure theory model. He pointed out that culture is not only a part of the superstructure but an overall way of life (Williams, 1958). Culture is the necessary link of social production and the basis of social existence, which helps to realize the unity of the base and the superstructure.

Back to the starting point of Marxist cultural theory, based on different analytical perspectives and taking experience as a breakthrough, the base/ superstructure theory model has been continuously reinterpreted and developed, effectively responded to disputes, expanded the connotation and extension of culture, and released the relative autonomy of culture. But too much emphasis on experience and the lack of abstract construction of cultural theory is strongly criticized by the second generation of the British New Left (e.g. Anderson, 1966; Hall, 1980). Stuart Hall believes that this cultural interpretation is naive humanitarianism and vulgar mass politics. Perry Anderson clarifies that the reinterpretation of the base/superstructure theory model of the first generation of British New Left has ignored the structure of ideology and gradually deviated from the original meaning of historical materialism. Terry Eagleton criticized Williams's cultural determinism who ignored the progressive relationship between 
the base and the superstructure. "I must confess first that I belong to that dwindling band who still believes that the base/superstructure model has something valuable to say." (Eagleton, 2000: p. 237).

Because in a class society, if the economy is not developed enough, culture is still subject to the superstructure and cannot surpass ideology. Through the release of the relative autonomy of culture, the British New Left tried to further stimulate the political liberation potential of culture, and they found a new path in criticizing elitism.

\section{Based on the Materialist Culture, Stimulate the Political Liberation Potential of Culture}

Based on the context of the 19th century, Marx and Engels followed the cultural concept in the anthropological sense, and mutually interpreted culture and civilization (Lu, 2018). On the one hand, it criticizes the spiritual interpretation of traditional culture and emphasizes the material meaning of culture. On the other hand, it upholds the enlightenment tradition of culture and requires the advancement of human liberation. However, since the 20th century, the traditional interpretation of the opposition between culture and civilization has been preserved, and culture has gradually been abstracted into elegance and interest (Williams, 1983). With the help of Matthew Arnold and F. R. Leavis, elitism has become very popular in Britain. However, mass culture has developed rapidly under the impetus of modernity, and the cultural crisis between elitism and mass culture has intensified.

The British New Left tried to base itself on the materialistic cultural outlook, criticize elitism, defend the culture of the working class from the perspective of multiple paradigms and analytical methods, and rectify the name of mass culture. They try to explore the revolutionary cultural traditions of the working class, dissolve the opposition between mass culture and elite culture, and stimulate the political liberation potential of culture (Williams, 1958; Thompson, 1957; Hoggart, 1957). They tried to dig out the revolutionary cultural traditions of the working class, dissolve the opposition between mass culture and elite culture, and stimulate the political liberation potential of culture.

\subsection{Based on the Ethnographic Analysis, Highlight the Routineness of Culture and Defend the Working-Class Culture}

Richard Hoggart, who was born in a working-class family, defended working-class culture, opposed the interpretation of culture by economic reductionist, and emphasized that culture is a kind of display, not an exploration, and is constructed in the practice of daily life (Hoggart, 1957). Therefore, Hoggart tried to show the daily life of the working class through ethnographic and cultural criticism analysis method. He attempted to demonstrate their cultural attitudes and political beliefs in community life, vividly interpret the commonality and routineness of culture, and explore the intrinsic value and significance of work- 
ing-class culture. But Hoggart has not yet shaken off the value scale of elite culture and has completely broken with culture and civilization tradition. Like the cultural industrialism of the Frankfurt School, he was full of contempt and extreme prejudice towards mass culture and youth subculture. He believes that they have eroded the routineness of working-class culture and are full of vulgar tendencies and sensory entertainment. However, Williams, Thompson, and others tried to break Hoggart's prejudice against mass culture, re-examine popular culture, and integrate mass culture and working-class culture to stimulate the political resistance potential of working-class culture.

\subsection{Based on the Analysis Paradigm of Cultural Materialism, Reconstruct Cultural Concepts and Rectify the Name of Mass Culture}

Following Hoggart's emphasis on the routineness of culture, Williams tried to reconstruct cultural concepts into a whole way of life through the paradigm of cultural materialism analysis (Williams, 1961). He tried to dig out the meaning and value of daily life, and understand the duality of culture from a holistic dimension. For Williams, culture is not only the perfection of the human soul at the ideal level, the knowledge and imaginative works at the document level, but also the specific lifestyle at the social level (Williams, 1983). By reconstructing cultural concepts, Williams tried to activate the connection between culture and society, transcend the opposition between elegant culture and mass culture, and use common culture to break the separation of working-class culture and bourgeois culture.

Unlike Hoggart's prejudice against mass culture, Williams emphasized that people's attitudes towards mass culture depend on changes in political positions. In elitism, mass culture is the culture of gangsters, while for the proletariat, it is a resistance force, and after a long revolution, it will move towards socialism with a common culture (Williams, 1961). Later, inspired by Thompson, Williams absorbed the factor of cultural struggles, revealed the political connotation of emerging media culture represented by television, and demanded resistance to capitalist cultural hegemony (Williams, 2004).

\subsection{Exploring the Revolutionary Cultural Traditions of the Working Class Based on the Historicism Analysis Paradigm}

Different from Hoggart's ethnographic investigation and Williams's cultural materialism analysis, Thompson is based on the paradigm of historicism analysis and understands culture from the practical activities of civilian. He emphasized that culture is a holistic way of struggle that is created in daily life based on the mode of production. Thompson tried to use a bottom-up ethnographic investigation to outline the changes in social relations behind the history of the struggle of the working class, defend the culture of the working class, and stimulate the subjectivity and initiative of the working class (Thompson, 1980). He emphasized that the civilian culture that emerged in British society in the 18th century 
was a class struggle method of working people against capitalism by using habits and traditional creativity. It was the source of the revolutionary tradition of the British working class and the driving force for the generation of class consciousness and the inheritance of radical traditions. Therefore, the English working-class culture is the best mass culture.

But in Anderson's view, this empirical materialist cultural view lacks ideological structure and can arouse the structural culture crisis (Anderson, 1966). He criticized Thompson's ethical defense of the British working class's revolutionary cultural traditions and was unable to launch a revolution and achieve human liberation. "Marxism aspires in principle to be a universal science-no more amenable to merely national or continental ascriptions than any other objective cognition of reality." (Anderson, 1979: p. 94). Anderson believes that Britain lacks a revolutionary cultural tradition and cannot spontaneously form a revolutionary theory and initiate a revolution. Britain needs to eliminate the narrowness of British nationalism, take the road of internationalism, transplant advanced Marxist theories from the European continent, and create a revolutionary culture and revolutionary theory. As a result, solving the structural dilemma and enhancing the struggle and revolution of culture have become an important cultural problem faced by the British New Left. Therefore, with the introduction of Althusser's ideological structure theory and Gramsci's theory (Gramsci, 2011) of hegemony to Britain, British New Left tried to in conjunction with ideology and hegemony theory to solve the structural dilemma of culture.

\section{In Conjunction with Ideology and Hegemony, Solve the Structure and Subject Dilemma of Culture}

After the 1970s, when the ideas of Althusser and Gramsci and others entered the vision of British New Left thinkers, "Another Marxist culture has emerged, with its magical speed and full self-confidence. First of all, the target of the standard is those economic, social or political-institutional issues that its predecessors have ignored." (Anderson, 1989: p. 18). Thus, the integration of culture, ideology, and hegemony has become a breakthrough for the British New Left to solve the structure and subject dilemma

\subsection{Turn to Structuralist Analysis Paradigm, Inject Ideological Factors, and Enhance the Structure of Culture}

The ideological theory is the core of Marx's cultural theory, but its connotation is multiple, meaning is uncertain, and it is easy to cause controversy ( $\mathrm{Lu}, 2018$ ). To a certain extent, Althusser's analysis of ideological theory from a broad practical perspective has responded to the controversy (Althusser, 2005). It was deeply recognized by Williams. To break through the structural dilemma of culture, Williams turned to the research paradigm of structuralism after the 1970s. He regards ideology as an independent function and structure that can organize society. From the epistemology point of view, Williams regards ideology as a 
general process of the production of various meanings and concepts, and highlights the function of ideology in the construction of culture. Originating from the controversy of the concept of ideology, he also created the concept of structure of feeling to replace ideology, emphasizing that the structure of feeling is the experience of a specific period and a particular cultural presupposition, which helps overcome empiricism and improve the abstract structure of culture (Williams, 1977).

Different from Williams' epistemological interpretation of ideology, Terry Eagleton adheres to historical materialism, focuses on understanding the concept of ideology from the political level, and insists on the decisive role of class on ideology. "Ideology is not in the first place a set of doctrines; it signifies the way men live out their roles in class-society, the values, ideas, and images which tie them to their social functions and so prevent them from a true knowledge of society as a whole." (Eagleton, 2003: p. 15).

Eagleton believes that ideology is not a false thought or illusion that hinders true historical concepts, but a net. Through ideology, some elements of reality can be shed, forming a kind of absence, allowing the text to present the authenticity of history. With the introduction of ideological factors and the shift of structuralism paradigm, culture is regarded as a place of experience and production meaning, making it possible for textual cultural studies and ideological studies of cultural practices (Davis, 2006). However, this structuralism text analysis overemphasizes the construction of subjectivity by language, and it is easy to ignore the role of the subject. Because relatively stable language cannot be equated with the changing reality, trying to understand social life with the logic of linguistics will inevitably lead to the requirement for structural consistency. Thus lack the investigation of real social history and historical subjects. In Thompson's view, this theoretical ideology can easily obscure the subject's initiative (Thompson, 1978). For Anderson, it is unscientific to use the relationship between language and speech to measure the relationship between structure and subject (Anderson, 1980). Excessive abuse of language is difficult to solve the predicament of subject and structure, and it is easy to lose historical subjectivity.

\subsection{Realize the Gramscian Turn, Introduce Hegemony, and Expand the Subject of Ideology}

Antonio Gramsci's theory of hegemony entered Britain in the 1970s and aroused a lot of attention from the British New Left. Because hegemony can trigger power and ideological struggle for the whole life, break the abstract unity structure of ideology, and show the struggle, consultation and compromise process of dominant culture and subordinate culture. They realize the Gramscian turn, in conjunction with hegemony theory, regarded culture as a process and practice by which subjects gave meaning to the world, and expanded the category of ideological subjects.

To complete cultural theory, Williams absorbed Gramsci's concept of hege- 
mony, regarded culture as a place of ideological struggle, and divided the whole culture into the dominant culture, residual culture, and emerging culture (Williams, 1977). It not only emphasizes the class status and historical subject of culture, but also highlights the complex relationship between different class cultures, i.e., there is a process of incorporation, resistance, and compromise. Although Williams still emphasizes the integrity and experience of culture, through hegemony, the subjectivity and struggle of culture are manifested, which is more helpful to grasp the inherent value and meaning system of culture from a practical level. It helps to actively shape-selective traditions and promote the creative transformation from tradition to modernity.

Influenced by postmodernism, Stuart Hall tried to in conjunction with hegemony, power discourse, and deconstructive thoughts in the face of the symbolic representations presented by marginal cultures such as British subculture, racial culture, and gender culture. He regards culture as a process of representation, showing the structural contradictory relationship between the subject and the other behind the marginal culture, revealing its ideological tension and potential for political resistance (Hall, 1980). With the help of encoding and decoding theory, Hall analyzed the youth-subcultural phenomena such as Teddy Boys, Moderate Youth, and Skinheads.

On the one hand, he emphasized the complexity of youth subculture, deconstructing the stereotype of subcultural groups, i.e., passive others, and emphasizing that they are active subjects with resistance potential The relationship between subculture and dominant culture exists both collusion and confrontation. Subculture not only intends to compete for hegemony, but also has the possibility of being incorporated. Therefore, they have maintained a state of coexistence and negotiation for a long time. On the other hand, he pointed out that youthsubcultural groups are scapegoats for capitalist social problems, and media discourse carries ideological functions and aims to distract people from economic crises and class conflicts, thereby maintaining capitalist hegemony. Thus, through the interpretation of symbolic representations and contradictory analysis of marginal cultures, Hall allows the cultural subjects to transcend class constraints and form a political form of multi-hegemony coexistence.

This kind of cultural studies paradigm, namely the Gramscian turn, brings hegemony into culture. The advantage of this paradigm lies in expanding the cultural connotation and ideological subject category, solving the structure and subject dilemma, and deepening the cognition of marginal culture. But the disadvantage is that the theme of cultural research has shifted from focusing on the economic exploitation of workers in the field of production to focus on the spiritual oppression of disadvantaged groups in the cultural field, from focusing on class inequality to focusing on gender or racial inequality, gradually deviating from realistic political goals and eliminating class conflicts. It breaks away from the critical framework of political economy, ignores the importance of class rule and state violence, and falls into the whirlpool of postmodernism. 


\section{Theoretical Analysis from the Perspective of Historical Materialism}

Facing the complicated and confusing cultural issues and the increasingly severe cultural crisis, classical Marxism is constantly being challenged. Based on the context of the times and changes in social reality, after multiple paradigm analyses and theoretical disputes, the British New Left focused on Marxist cultural theory and broadened the interpretation space of Marxist cultural theory from the level of content, method, and paradigm. However, confined to the perspective of historical materialism, their theoretical interpretation weakens the critical strength of the Marxist political economy, ignoring the importance of proletarian political parties, and tends to fall into the vortex of cultural determinism and postmodernism. Therefore, the two-sided theoretical heritage is left, which provides important enlightenment and reference value for the Sinicization of Marxist cultural research and the construction of Socialist culture.

\subsection{Create a New Paradigm for the Study of Marxist Cultural Theory, Highlighting the Characteristics of the Times, Nationality, and Interdisciplinary}

The enrichment and development of the Marxist cultural theory of the British New Left were due to the reflection on the cultural crisis caused by dogmatic Marxism and elitism. It creates a new paradigm of Marxist cultural theory with British characteristics, whether it is the analysis of the cultural materialism paradigm of Williams, the analysis of the historicism paradigm of Thompson, or the interpretation of the late structuralism paradigm and the Gramscian turn. In the continuous reconstruction of cultural concepts, these paradigms demonstrate the characteristics of the times, nationalities, and interdisciplinary, and have a wide range of influence and far-reaching significance.

Different from the 19th century in which Marx lived, the polarization between the rich and the poor and class conflicts were extremely fierce. In the 20th century in which the British New Left was living, with the advent of an affluent society and the prevalence of consumerism, British society was permeated with "classlessness" and continued to downplay revolutionary consciousness. Especially under the impact of American-style entertainment culture, mass culture and mass media have flourished and gradually formed a pattern of cultural pluralism. But unlike the Frankfurt School's critical attitude of cultural industrialism, it originated from the background of working-class families. The British New Left, headed by Hoggart and Williams, tends to criticize elitism based on the empirical tradition and the daily life experience of the working class. They have unique "Britishness" and contemporary characteristics. To solve the theoretical and methodological crisis of the British native humanities, they continued the innovative spirit of Marx's interdisciplinary research and opened up a new path of cultural research in the theoretical disputes. Whether it is Hoggart and Thompson's ethnographic analysis of working-class culture or Williams and 
Hall's linguistic analysis of mass culture and its emerging forms, they all have distinct interdisciplinary characteristics, innovate the research methods of Marxist cultural theory.

\subsection{Weaken the Critical Strength of the Marxist Political Economy and Ignore the Importance of Proletarian Political Parties}

After the transformation of multiple paradigms and theoretical disputes, the British New Left continued to reconstruct cultural concepts based on historical materialism, which eased the cultural crisis to a certain extent, broke the shackles of dogmatic Marxism and elitism, and solved the structure and subject dilemma. However, due to the historical materialism vision and the excessive expansion of the connotation and extension of cultural concepts, after the 1970s, the subject of British New Left cultural studies gradually shifted from class politics to identity politics or symbol politics. Their focus has gradually shifted from the economic exploitation of the working class to the spiritual oppression of the marginalized groups. They use text analysis and discourse analysis to replace the capitalist material production mode analysis, which is easy to fall into the vortex of cultural determinism and postmodernism. This weakens the critical strength of the Marxist political economy and shakes the position of the socialist revolution. "It is very difficult to see how a process, in which only certain people have the power and cultural authority to ensure the canonical reproduction of texts and practices, can be described as simply an effect of a text's polysemy." (Storey, 2012: p. 201).

Although the British New Left saw the political liberation potential of culture, they tried to engage in active political intervention on the premise of cultural politics. In particular, the first generation of British New Left such as Williams and Thompson, has worked in adult education, trying to arouse the political demands of working-class culture and remove the fog of "classlessness". Revive the revolutionary consciousness of the masses in the long revolution and open up the "third way" of socialism. However, after World War II, out of disappointment that the British Communist Party and the Labor Party succumbed to Stalinism, their cultural and political practices and cultural studies must have the characteristics of "de-party struggle" and gradually fell into text analysis and discourse struggle research. In particular, Hall, in his later period, has drifted away from Marxism, obsessed with the study of representational politics and cultural identity (Xu, 2014).

Although their cultural studies, to a certain extent, revealed the ideological functions of mass culture and media culture, aiming at the hegemony of capitalist culture. However, this view has stagnated in the cultural criticism of capitalism, ignoring the premise of overthrowing capitalism, i.e., the weapon of criticism can only play a revolutionary role with the help of weapon criticism. It takes proletarian parties to unite and lead the working class in a class struggle to overthrow capitalist rule. To solve the structure and subject dilemma, the British 
New Left shifted to the Gramscian turn, reconstructed culture as a place of ideological struggle, in conjunction with hegemony, expanded the subject of ideology, and presented the process of the incorporation, resistance, and compromise between the subject and the other.

But in conjunction with Gramsci's hegemony theory, they ignore the investigation of the political economy dimension, and divorcing the investigation of capitalist political economy. Because Gramsci's theory of hegemony is vague, it exaggerates the role of civil society and separates economic factors from civil society. Therefore, the absorption of this hegemonic theory that draws away from economic factors will inevitably go against the principle of historical materialism to examine the real movement. It let the hegemonic culture break away from the material production conditions, stay at the abstract surface of social phenomena, and weaken the strength of reality and logic. Therefore, they cannot realize the key role of actual material forces and the importance of the proletarian party. Instead, they choose to abandon the party or class struggle goal, showing the weakness of theory and the fragility of belief. But to truly criticize the capitalist society and exert the tension of ideological criticism, it is necessary to strengthen the historical materialistic foundation of Marxist cultural theory.

\subsection{Provide Important Enlightenment for the Sinicization of Marxist Cultural Research}

In the process of advancing Marxist cultural research, the British New Left has combined with the changes in British social reality, critically absorbed the essence of elite culture and mass culture, carried forward the value of excellent traditional culture, and actively absorbed the theoretical resources of the European continent. It creates a model of effective integration of Marxist cultural theory with British native national culture and has important enlightenment for promoting the Sinicization of Marxist cultural research. It is necessary to base itself on China's practice and actively respond to major theoretical and practical issues of concern to the people.

With the development of cultural globalization and the mutual turbulence of multicultural thoughts, Marxist "outdated theory" and "useless theory" and other wrong tendencies are rampant, and the problem of Marxist identity has gradually emerged. But "theory is capable of gripping the masses as soon as it demonstrates ad hominem, and it demonstrates ad hominem as soon as it becomes radical.” (Marx \& Engles, 2010: p. 182). It is necessary to adhere to the Sinicization of Marxist cultural research.

To study the Sinicization of Marxist cultural research, it is necessary to clarify what kind of Marxism does China needs? How to realize Marxism? From a content perspective, we must base ourselves on contemporary Chinese practice, maintain the integrity and innovate, continue to integrate Marxism with Chinese excellent traditional culture, integrate with world culture, respond to major issues of people's concern, and constantly use Marxism to observe, grasp and lead the era and develop contemporary Chinese Marxism and 21st century Marxism. 
From a path point of view, on the one hand, we must use the intellectual support of elite culture, combined with popular language, to promote the nationalization, concretization, and popularization of Marxism, continue to carry out theoretical innovation and urge cultural institutions and intellectuals to create cultural products that meet the spiritual needs of the masses. On the other hand, we should play a positive role in mass culture and make critical use of mass culture. It is necessary to supervise and improve the mainstream culture, and ensure the people's standpoint.

\subsection{It Has Inspiration for the Construction of Socialist Culture with Chinese Characteristics}

Facing the impact of American entertainment culture and the sweeping of popular culture, based on the materialistic cultural concept, the British New Left adhered to a bottom-up people's standpoint, and to a certain extent, defended the value of the working-class culture. A dialectical look at the role of mass culture reveals the ideological function behind media culture. However, in the active political intervention, they focus on the struggle for de-party, and gradually turn to the study of representational politics and media politics in cultural and political practice, and finally abandon the goal of party or class struggle, and ignore the importance of proletarian party and class analysis. It has important enlightenment for the construction of Socialist culture with Chinese characteristics. It is necessary to adhere to the leadership of the Communist Party of China (CPC), put the people as the center, and truly let "theory also becomes a material force as soon as it has gripped the masses" (Marx \& Engels, 2010: p. 182). It provides spiritual motivation, intellectual support, and ideological guarantee for the modernization of Socialism with Chinese characteristics.

The world is marked by changes unseen in a century. China's popular culture has been influenced by European and American popular culture for a long time. There is a phenomenon of cultural commercialization and entertainment, and popular culture is increasingly occupying people's leisure lives. Therefore, in advancing the construction of Socialist culture, it is necessary to properly handle the relationship between mass culture and Socialist culture. Affected by Chinese traditional culture and historical materialism, China's popular culture contains a people-oriented position. It is "the modern link of the free sequence of the people at the bottom, which is close to, entertaining, activating and improving the lives of the masses, but it cannot get rid of the logic of capital and its hierarchical limitations, and it has the characteristics of commercialization, materialization, entertainment, and vulgarization" (Liu, 2020: p. 155). Therefore, we must combine our uniqueness and treat Chinese mass culture dialectically.

On the one hand, we must adhere to the people-centered approach, satisfy the people's cultural needs and strengthen the people's spiritual strength. Make full use of media resources and network fields, and unleash the creative spirit of the people and the positive influence of popular culture. Spread Chinese excellent 
cultural traditions and the positive energy of Socialist culture. Based on satisfying entertainment and leisure, guide the public to maintain a positive outlook. On the other hand, we must uphold the leadership of the Chinese Communist Party (CPC). It is necessary to guard against some unhealthy mass culture. Guide the public to enhance their ability to discern popular culture, and consciously resist vulgar culture.

\section{Conclusion}

To sum up, British New Left face changes in social reality and cultural crises in post-war Britain. In the multi-paradigm analysis, they constantly reconstruct cultural concepts and expand the interpretation space of Marxist cultural theory. It releases the relative autonomy, political liberation, and struggle of culture, and demonstrates the contemporary, national and interdisciplinary nature of British Marxist culture studies. However, in the course of theoretical breakthroughs, they have over-expanded the connotation and extension of cultural concepts, exaggerated the role of culture, failed to properly handle the relationship between culture, economy, and politics, and fell into the stereotype of cultural determinism. In the connection and deconstruction of cultural theories, they have fallen into textual analysis and discourse struggles, and are getting closer and closer to abstract ideas, weakening the criticism of Marxist political economy, falling into the whirlpool of postmodernism, and loosening the foundation of materialist cultural concepts. However, the double-sided Marxist cultural theoretical heritage left by the British New Left still contains important theoretical enlightenment. It should strengthen tracking and research, open up a new realm for the development of contemporary cultural studies.

\section{Acknowledgements}

The author gratefully acknowledges the support of the Shanghai Youth Project Fund for Philosophy and Social Science Planning (2019EKS007).

\section{Conflicts of Interest}

The author declares no conflicts of interest regarding the publication of this paper.

\section{References}

Althusser, L. (2005). For Marx (Vol. 2). Verso.

Anderson, P. (1966). Socialism and Pseudo-Empiricism. New Left Review, 35, 2-42. https://newleftreview.org/issues/i35/articles/perry-anderson-socialism-and-pseudo-em piricism

Anderson, P. (1979). Considerations on Western Marxism. Verso.

Anderson, P. (1980). Arguments within English Marxism. Verso.

Anderson, P. (1989). In the Tracks of Historical Materialism. Oriental Publishing House.

Davis, M. (2006). The Marxism of the British New Left. Journal of Political Ideologies, 11, 
335-358. https://doi.org/10.1080/13569310600923949

https://www.tandfonline.com/doi/abs/10.1080/13569310600923949

Dworkin, D. (1997). Cultural Marxism in Postwar Britain: History, the New Left, and the Origins of Cultural Studies. Duke University Press.

Eagleton, T. (2000). Base and Superstructure Revisited. New Literary History, 31, 231-240. https://www.jstor.org/stable/20057599 https://doi.org/10.1353/nlh.2000.0018

Eagleton, T. (2003). Marxism and Literary Criticism. Routledge. https://doi.org/10.4324/9780203361771

Gramsci, A. (2011). Prison Notebooks (Vol. 2). Columbia University Press.

Hall, S. (1980). Cultural Studies: Two Paradigms. Media, Culture \& Society, 2, 57-72. https://journals.sagepub.com/doi/10.1177/016344378000200106 https://doi.org/10.1177/016344378000200106

Hoggart, R. (1957). The Uses of Literacy. Transaction Publishers.

Hu, H. B., \& Guo, F. Z. (2010). The Cultural Theory of Marx and Engels: An Important Perspective of Hidden Historical Materialism. Academic Monthly, 1, 42-48.

Huang, L. Z. (2002). On the Contemporary Construction of Marxist Cultural Philosophy. Shandong Social Science, 2, 47-53.

Kellner, D. (2021). Cultural Marxism, British Cultural Studies, and the Reconstruction of Education. Educational Philosophy and Theory, 7, 1-13. https://doi.org/10.1080/00131857.2021.1926982

Kenny, M. (1995). The First New Left: British Intellectuals after Stalin. Lawrence \& Wishart.

Li, W.W., \& He, P. (1989). An Outline of Marxist Cultural Philosophy. Journal of Wuhan University, Social Science Edition, 4, 22-28.

Lin, C. (1993). The British New Left. Edinburgh University Press.

Liu, R. (2020). An Analysis of Popular Culture under the Three-Dimensional Perspective of History, Structure, and Comparison. Academic Exploration, No. 8, 155.

Liu, T. F. (2011). The Dimension of Marx's Cultural Liberation and Its Political Purpose. Tianjin Social Science, 3, 10-14.

Lu, Y. (2018). The Development History of Marxist Cultural Theory. Baihuazhou Literature and Art Publishing House.

Lukács, G. (1972). History and Class Consciousness: Studies in Marxist Dialectics. MIT Press.

Marx, K., \& Engels, F. (2010). Marx \& Engels Collected Works, Vol. 3. In J. Cohen, R. Dixon, C. Dutt et al. (Eds.), Marx and Engels: 1843-1844. Lawrence \& Wishart.

Storey, J. (2012). Cultural Theory and Popular Culture: An Introduction (5th ed.). Routledge.

Sun, D. Y., \& He, H. G. (2011). The Cultural View of Marx and Engels and Its Contemporary Value. Theoretical Journal, 7, 16-21.

Thompson, E. P. (1957). Socialist Humanism. The New Reasoner, 1, 105-123.

Thompson, E. P. (1978). The Poverty of Theory. NYU Press.

Thompson, E. P. (1980). The Making of the English Working Class. University Press.

Williams, R. (1958). Culture and Society, 1780-1950. Columbia University Press.

Williams, R. (1961). The Long Revolution. Columbia University Press. https://doi.org/10.7312/will93760 
Williams, R. (1977). Marxism and Literature (Vol. 392). Oxford University Press. Williams, R. (1983). Culture and Society, 1780-1950. Columbia University Press. Williams, R. (2004). Television: Technology and Cultural Form. Routledge. https://doi.org/10.4324/9780203426647

Xu, D. L. (2014). Hall: “No Guarantee” Marxist. Literature and Culture, 2, 69-77.

Yu, J. X. (2001). Marxist Cultural Theory and Modern Times. Chinese Social Science, 6, 14-23. 